\title{
New Antisemitism and New Media: Leftist Derealization of Islamist "Emancipation"
}

Jean Améry referred to leftist anti-Zionists as "ehrbare Antisemiten"-virtuous antisemites. ${ }^{1}$ While far-right antisemitism had been delegitimized after the defeat of the Nazis, and its proponents now communicate in codes, directing their resentment, for instance, at "the East coast," leftist antisemites present themselves as antifascists. ${ }^{2}$ This paper-presented as part of the "Internet and Antisemitism" panel-argues that this distinction also influences the logic of how leftist antisemites use the new media. Before I elaborate on this theory-driven hypothesis with regard to "Antisemitism 2.0," it must be clarified that leftist antisemitism is best understood as one variant of modern antisemitism in its post-Holocaust transformation. ${ }^{3}$ I will then introduce the term "new antisemitism" to describe a far-reaching ideological convergence of antisemitism since 9/11 and the "Second Intifada" across a range of ideologies and milieus that traditionally had precious little in common. ${ }^{4}$ At its heart lies a form of antisemitic anti-Zionism that unites Islamists with many on the Far Right and the Left.

The second, empirical part of my contribution analyzes the impact of this new antisemitism on discussions in leftist new media. I will focus specifically on the reactions to the Hamas policy paper of 2017, which some erroneously understood as a new Hamas Charter. The portrayal of Hamas, by parts of the Left, as the moderate variant of political Islam willing to integrate, as an emancipatory movement struggling for political freedom is almost as old as the original Hamas Charter. When in 2017 various leftists suddenly acknowledged Hamas's antisemitism of the past, they did so only in order to assure us that, with this

1 J. Améry, "Der ehrbare Antisemitismus: Rede zur Woche der Brüderlichkeit," in Weiterlebenaber wie? Essays 1968-1978 (Stuttgart: Klett-Cotta, 1982), 151-75.

2 C. Kohn-Ley, “Antisemitische Mütter-antizionistische Töchter?," in Der feministische "Sündenfall"? Antisemitische Vorurteile in der Frauenbewegung, ed. C. Kohn-Ley and I. Korotin (Wien: Picus, 1994), 209-30; D. Hirsh, Contemporary Left Antisemitism (London: Routledge, 2018), 1.

3 Cf. T. Haury, Antisemitismus von links: Kommunistische Ideologie, Nationalismus und Antizionismus in der frühen DDR (Hamburg: Hamburger Edition, 2002). Of course the "left" is a very unspecific term; here it applies to a broad spectrum from center-left positions to the lunatic fringe in post-national socialist Germany and Austria.

4 Cf. D. Rabinovici et al., eds., Neuer Antisemitismus? Eine globale Debatte (Frankfurt am Main: Suhrkamp, 2004).

Ә OpenAccess. ( 2021 Armin Lange, Kerstin Mayerhofer, Dina Porat, Lawrence H. Schiffmann, published by De Gruyter. (cc) BY-NC-ND This work is licensed under the Creative Commons Attribution-NonCommercialNoDerivatives 4.0 International License. https://doi.org/10.1515/9783110671964-008 
new policy paper, the Islamist terror organization really had now repudiated the antisemitic parts of the 1988 Charter. This speaks to a high level of "derealization," whitewashing Hamas's Islamist antisemitism in the wake of its ostensible change of heart, which, as I will show, can be witnessed in various new media.

Given that antisemitism has increased considerably over the last ten years not only in the social media, ${ }^{5}$ but also in the online comment sections of quality media, ${ }^{6}$ in the final part of the essay, I present relevant posts to the discussion forum of the Austrian center-left daily Der Standard in the wake of the publication of the Hamas policy paper, demonstrating, not least, that the denial of Islamist antisemitism can go hand in hand with the portrayal of Muslims as the new Jews. ${ }^{7}$

\section{From Modern to New Antisemitism}

That antisemitism is not some marginal phenomenon found only among farright activists or Neo-Nazis should go without saying by now. If one wants to explain its various guises in general, and leftist and "new" antisemitism in particular, one needs to understand what antisemitism is and why antisemitic explanations play to people's needs. Some authors stress the continuities between religious anti-Judaism before the Spanish inquisition and Martin Luther's late conviction that Jews cannot become true Christians through baptism, on the one hand, and modern antisemitism, on the other. By contrast, I stress both the continuities and the rupture, which went hand in hand with the transformation from pre-modern to modern, capitalist society. I will first address the conditions under which modern antisemitism developed, surveying how it can be explained in social, economic, and psychological terms. I will then discuss the transformation of antisemitism after the Holocaust, the emergence of so-called secondary, post-Holocaust antisemitism, and its expression on the political Left. Finally, I will touch on the so-called "new antisemitism," the convergence,

5 Cf. World Jewish Congress and Vigo Social Intelligence, The Rise of Antisemitism on Social Media: Summary of 2016 (New York: World Jewish Congress, 2016), 8.

6 Cf. M. Schwarz-Friesel, Antisemitism 2.0 and the Cyberculture of Hate: Hostility towards Jews as a Cultural Constant and Collective Emotional Value in the Digital Age (Short Version) (Berlin: Technische Universität Berlin, 2018), 7, https://www.linguistik.tu-berlin.de/fileadmin/fg72/Anti semitism_2.0_short_version_final2.pdf.

7 Cf. M. Schwarz-Friesel and E. Friesel, “'Gestern die Juden, heute die Muslime...’? Von den Gefahren falscher Analogien," in Islamophobie und Antisemitismus-ein umstrittener Vergleich, ed. G. Botsch et al. (Berlin: de Gruyter, 2012), 29-50. 
since 9/11, of far right, Muslim, and left-wing antisemitism on the basis of their shared anti-Zionism.

\section{Modern Antisemitism}

The Frankfurt School in general and Theodor W. Adorno and Max Horkheimer in particular did not want to acquire expert knowledge on political extremism but analyze society as a whole through the prism of the most terrible consequence generated by the principles of its formation. Antisemitism takes centre stage in the development of this critique because it facilitated the relapse into barbarism and unites all the destructive traits generated by the unfree society. The relapse into barbarism is analyzed as a potentiality of the modern world that culminated in Auschwitz and the other sites of annihilation, yet whose prerequisites persist.

The point of departure is the assumption that modern antisemitism developed in tandem with bourgeois-capitalist society. It followed on from pre-modern forms of anti-Jewish sentiment and took over the object of their hatred. In Europe, the tradition of Christian anti-Judaism was of particular significance in this context. Modern antisemitism was originally a response to the emergence of capitalism and the dramatic social changes it brought with it. The direct relations of dependence in feudal society ceded to indirect and abstract forms of rule, characterized by Marx as the silent compulsion of economic relations. ${ }^{8}$ The new societies nailed the values of freedom and equality to their mast. These were concepts which, though diametrically opposed to domination and exploitation in formal terms, were in fact their indispensable complement and ideological representation.

Emancipation from the barriers of feudalism in general encompassed the emancipation of the Jews after centuries of exclusion and discrimination. Jews gained access to social spheres from which they had long been excluded and were able to gain a footing in new professions, especially in the cities. The Christian majority populations who were traditionally ill-disposed toward the Jews encountered them as "colonizers of modernity." The connection between the emancipation of the Jews and the apparent threat of modernization seemed self-evident. It was in particular all those changes that contradicted the tradi-

8 Cf. K. Marx, Das Kapital: Kritik der politischen Ökonomie (Berlin: Dietz, 1993), 1:765.

9 M. Horkheimer and T. W. Adorno, Dialektik der Aufklärung: Philosophische Fragmente (Frankfurt am Main: Suhrkamp, 1997), 184. 
tional feudal way of life with all its rigid rules that were experienced as threatening. Large parts of the population rightly assumed that they would lose out when confronted with the dynamics of modern society that had been unleashed by the dictates of the accumulation of capital. Henceforth, not the coherent set of traditional rules would determine one's life but one's success or lack thereof on the market. Discontent with the uncomprehended mechanisms of a commodified society was targeted at the Jews. Modern antisemitism essentially results from the personalization of social relations under the rule of capital and the state. In ideological disputes, the "Jewish question" was stylized as the core of all social antagonisms. In the imagination of the antisemites, all the contradictions within their distorted image of "the Jews" were resolved through the myth of an alleged Jewish world conspiracy. Thus, it was possible to associate everything negative with one superior enemy.

Modern antisemitism is a particularly perfidious fetish. The supposedly "abstract" aspects of capitalism (value, capital, interest, etc.) are juxtaposed to its supposedly "concrete" dimensions (the use value of the commodity, labour, production, etc.). The antisemite distinguishes between good, "productive" and bad, "exploitative" capital. Antisemitism thus emerges as a form of reductionist "anticapitalism." Because it targets only the abstract side of capitalism, antisemitism is highly compatible with continued domination. Far from formulating a radical critique of the existing order, it perpetuates and consolidates the submission of the individual to the laws of modern society enforced by state and capital. The antisemites are only too familiar with the characteristics they project on to the Jews, since they in fact reflect their own repressed wishes and desires. Whatever contradicts the necessary self-denial of the subjects, whatever they cannot or may not admit to themselves, is ascribed to the Jews, in order then to affirm one's self-denial by persecuting it in them.

Antisemitism is therefore an authoritarian rebellion. An impulse that potentially points toward a radical critique of society, both in theoretical and practical terms, is neutralized, mutilated, and transformed into its opposite. In a society of domination and unfreedom, the sense that things might be different has to be persecuted. The Jews thus fall prey to a ritual that one could describe as a modern form of exorcism. By attacking the Jews, the antisemites reassure themselves of their belonging to an ostensibly natural national collective that is meant to protect its members from the sometimes catastrophic consequences of life in capitalist society. As the subjects realize how little substance underpins their subjectivity, they flee into the imagined protective community of the nation. "Na- 
tional mobilizations," in Horkheimer's words, "are the permitted alternative to revolution."10

For the overwhelming majority, the successful constitution of the subject is possible only if they manage to realize the sole commodity, which they still have at their disposal once they have been freed from the previous social relations and face each other as atomized individuals: their labour. Yet their success or lack of success in realizing this commodity lies beyond the individual subject's sphere of influence. Consequently, subjectivity is an ideological construct in bourgeois society. Horkheimer and Adorno are referring to this thwarted liberation when they write that the antisemitic reaction is triggered in situations in which "deceived human beings who have been robbed of their subjectivity are set loose as subjects"11

We are dealing, then, with a damaged subject. It is damaged because, in the interest of self-preservation, it has to place demands on itself, which it cannot actually meet by itself. In psychoanalytic terms: the subject is forced to hypostatize itself in a narcissistic fashion, which, in turn, inevitably sets it up for narcissistic injury. The "specific motives" underlying antisemitism Freud identified as those that spring "from secret sources." 12 Yet, it should not be forgotten that the psychology of the individual is socially grounded. While the laws of society cannot be derived from the psychological profiles of individuals, the individual is

not merely an individual and the substratum of psychology but always also ... a carrier of the social regulations that shape it. ... Even the vulgar materialism that explains individual responses with tangible profit interests is right when compared to the psychologist who derives the economic behavior of adults that conforms to objective economic laws from their childhood. ${ }^{13}$

The studies on The Authoritarian Personality ${ }^{14}$ revealed that antisemitism is complemented by various other character traits, all of which together constitute the authoritarian personality. It is interpreted as the outcome of an upbringing in a

10 M. Horkheimer, "Die Juden und Europa," in Wirtschaft, Recht und Staat im Nationalsozialismus: Analysen des Instituts für Sozialforschung 1939-1942 von Max Horkheimer, ed. H. Dubiel and A. Söllner (Frankfurt am Main: Suhrkamp, 1984), 44. This and all the following quotes from German texts were translated by the author.

11 Horkheimer and Adorno, Dialektik der Aufklärung, 180.

12 S. Freud, "Mann Moses und die monotheistische Religion," [1939] in Studienausgabe IX (Frankfurt am Main: Fischer, 2000), 139.

13 T. W. Adorno, "Zum Verhältnis von Soziologie und Psychologie," [1955] in Soziologische Schriften 1 (Frankfurt am Main: Suhrkamp, 1999), 49-50.

14 Cf. T. W. Adorno et al., The Authoritarian Personality (New York: Harper \& Row, 1950). 
patriarchal family with a dominant father figure that is characterized by a lack of affection, strict discipline, the trivialization of inward processes, and a rigid orientation toward external conventions. This sort of upbringing obstructs a successful integration of the super ego. Children are unable to develop a stable ego capable of creating an equilibrium between the urges of the id and the social norms and constraints established in the super ego. The resulting weakness of the ego creates a predisposition in the individual to follow external authorities and conventions in their thoughts and actions rather than their own judgments and to avoid making judgments of their own in the first place. Typical traits of this authoritarian syndrome are "rigid conventionality as well as unreflective adherence to social norms and regulations"15 and a conformism that "expresses alarm whenever social deviation occurs.”16

Since the experience of impotence cannot be admitted, it is psychologized into the "feeling of impotence." Individuals "are incapable of experiencing their impotence and looking it into the eye." Hence, "they have to process their impotence into a 'feeling' and turn it into a psychological sediment."17 This sense of impotence contradicts the narcissistic hypostatization of the self and as long as the actual causes of this constellation remain opaque for the individual it is likely to look for somebody to blame. The only thing it knows for sure is that it is definitely not to blame.

A rigid, moralizing upbringing leads to the repression of illicit feelings and the constant need to prevent them from becoming conscious again. Since this absorbs a considerable amount of energy, it represents a great relief if one can project the illicit feelings on to "alien" others. In other words, one of the means of resistance against the efforts of unconscious wishes and desires to resurface consists in seeing those wishes and desires in others while refusing to acknowledge them in oneself. Arbitrary projections are facilitated by an insufficient ability to distinguish between fantasy and reality. Those who can only see in the victims of their delusion those traits that they have repressed or cannot admit to themselves, are essentially impervious to experience. Borrowing from Kant, one could say that for an antisemite, antisemitism forms the a priori of all possible experience. All objects of experience are always already shaped in a particular way, as a result of which contradictory perceptions are rendered entirely impossible.

15 L. Rensmann, Kritische Theorie über den Antisemitismus: Studien zu Struktur, Erklärungspotential und Aktualität (Berlin/Hamburg: Argument, 1998), 39.

16 A. Silbermann, Der ungeliebte Jude: Zur Soziologie des Antisemitismus (Zürich: Interfrom, 1981), 40.

17 Adorno, "Zum Verhältnis," 74. 
The authoritarian personality "feels challenged and threatened by those people who deviate from the irrational and authoritarian structure of repression." 18 Qualities such as freedom, equality, and emancipation, which bourgeois society has been unable to realize, are attributed to "the Jews." Individuals find their narcissism constantly injured as they are forced to sell themselves day by day on the labour market, painfully aware of their replaceability. They have hundreds of wishes and understand the system well enough to know they will never be fulfilled. Yet buried deep down within them, they suspect that there might be more, they sense the possibility of "happiness without power, reward without work, a homeland without frontiers.”19

The timeless antisemitic notion that Jews are greedy and exploitative shrouds the unconscious envy of those who supposedly do not need to work and receive everything for free and without having to make an effort. Above and beyond the racist projection that hates and envies Black people because of their imagined hyper-sexuality and foreigners because they supposedly do not have to work, antisemitism also encompasses the alleged omnipotence of the Jews. While racists may envy individual foreigners because of their apparent "right to laziness," the latter nevertheless remains as powerless vis-à-vis the system as the former. The ostensibly powerful "Jew," by contrast, is also hated and envied because of his omnipotence. Against this backdrop, "the quotidian religion of antisemitism offers guilty victims suited as objects of the conformist rebellion." 20 In contrast to the victim of racism who is supposedly inferior, "the Jew" makes for an apt personification of negative authority because of his alleged intention to dominate the planet and his omnipotence. This is the crucial distinction between racism and (modern) antisemitism. Above and beyond all the benefits of racist projection, antisemitism offers the opportunity to act out not against the actual authorities but against others who are supposedly in a position of authority, and thus to rebel without harming one's own collective.

\section{Secondary, Post-Holocaust Antisemitism-Rightwing and Leftwing}

Secondary antisemitism is a particular form of modern antisemitism that has been shaped by the Holocaust. It seems inevitable that the attempt to annihilate

18 Rensmann, Kritische Theorie, 74.

19 Horkheimer and Adorno, Dialektik der Aufklärung, 225.

20 W. Bohleber and J. S. Kafka, eds., Antisemitismus (Bielefeld: Aisthesis, 1992), 168. 
European Jewry, which nearly succeeded, has had an effect on the concept and manifestation of antisemitism. In Germany and Austria, it is certainly impossible to analyze antisemitism, be it as a social or individual phenomenon, without considering the transformed circumstances following the genocide. The situation has changed insofar as an unreserved affirmation of the nation was no longer possible once the crimes had become public knowledge. In Germany and Austria, Auschwitz has become synonymous with an injury to the collective narcissism. Its recollection is affectively charged in a strong way and triggers public responses that clearly reveal the desire to deny, forget, keep secret, and relativize. Leaving to one sense a core of inveterate Jew haters, antisemitism after Auschwitz is antisemitism because of Auschwitz. Against this backdrop the contentions of modern antisemitism are recycled and modified.

Adorno already analyzed numerous evasion strategies of this kind in the 1950s. ${ }^{21}$ Take the example of the call that a line should finally be drawn beneath the past that is constantly raised in public debate as though it broke a major taboo for the first time. In fact, this has been a constant feature of "coming to terms with the past" in Germany and Austria since the late 1940s.

Austria has made its own original contribution in this context by styling herself as the first victim of National Socialism. To be sure, self-victimization is not unknown in the Berlin Republic either. The annual commemoration of the Allied bombing of Dresden is an obvious case in point. Even so, the current German state, as the successor state to Nazi Germany, has not been able to evade the past in quite the same way as Austria.

Secondary antisemitism is particularly dangerous insofar as it allows it proponents to see themselves as the innocent victim acting in self-defense. Modern antisemitism's paranoid conspiracy theories are rarely still propagated openly. The notion that an international Jewish community is working in a clandestine manner to destroy and subjugate the non-Jewish peoples may still enthuse a surprisingly large audience but, currently at least, it does not resonate with the broad masses. The contention that Jews are globally instrumentalising the Holocaust for their ends, on the other hand, seems very popular. By thinking of oneself as an individual who merely wants to be left in peace to lead a decent life but is prevented from doing so by "certain circles" who are, in fact, seeking revenge, anti-Jewish aggression appears simply as a form of self-defense.

21 Cf. T. W. Adorno, "Was bedeutet: Aufarbeitung der Vergangenheit," in Gesammelte Schriften 10.2. Kulturkritik und Gesellschaft II: Eingriffe. Stichworte (Suhrkamp: Frankfurt am Main, 1977), 555-72. 
While secondary antisemitism draws its momentum from the confrontation with the past, it is not merely backward-directed. It does not differ in principle from modern antisemitism but adapts it to the circumstances of post-Holocaust society. ${ }^{22}$ Secondary antisemitism thrives not despite but because of Auschwitz. At its heart is the desire to forget the National Socialist crimes and rid oneself of related negative feelings. This paradoxical constellation has aptly been summarized in the contention that the Germans will never forgive the Jews for Auschwitz.

In contrast to that, antisemitism on the Left springs not so much from the desire to engage in unreserved affirmation of one's own nation but has more to do with prevalent left-wing concepts of capitalism and imperialism, state and nation, fascism and National Socialism. Many on the Left have reduced National Socialism to a particular heinous form of class domination by the most aggressive parts of the bourgeoisie. ${ }^{23}$ For the longest time the annihilatory antisemitism of the Nazis was largely ignored or understood functionally as a means of domination and distraction deployed in the interest of goals other than the annihilation of European Jewry.

The traditional Left conceptualizes capitalism not as fetishized social totality that should be criticized for its reification of social relations but rather as the total sum of all capitalists with whom the working class finds itself in constant irreconcilable conflict. This inevitably generates a binary, reifying, personalizing, and moralizing imaginary, which hinges on the notion of a clique of evil rulers who rely on direct repression and blunt propaganda and who corrupt the working class with social policy, in order to dominate the ruled.

Critique and activism are thus directed not against a particular set of social relations but against the people who actually or allegedly represent one side of these social relations, and herein lies the structural analogy to antisemitism. Consequently, many on the Left also subscribe to a reductionist concept of imperialism that identifies it with foreign rule and exploitation by foreign capital. The uncritical identification with movements of national liberation in the developing world has led to the affirmation of categories such as state, nation, and people. This kind of anti-imperialism, which cannot distinguish between the critique of imperialism and unreserved partisanship for the victims of imperialism almost

22 Cf. L. Rensmann, "Guilt, Resentment, and Post-Holocaust Democracy: The Frankfurt School's Analysis of 'Secondary Antisemitism' in the Group Experiment and Beyond," Antisemitism Studies 1, no. 1 (2017): 4-37.

23 Cf. T. Haury, "Die Ideologie, die nicht vergehen will: 35 Jahre antisemitischer Antizionismus in der Neuen deutschen Linken," in Trotz und wegen Auschwitz, ed. AG Antifa/Antira im StuRa der Uni Halle (Münster: Unrast, 2004), 111. 
inevitably leads to collaboration with dictators, völkisch nationalists, and antisemites. $^{24}$

After the Six-Day War in 1967, leftist antisemites have come to depict Israel as an imperialist Goliath who should know better-given his experience of the Shoah-than to behave like the new Nazis and make Arabs in their country the new Jews of today. In contrast to the right-wing antisemites, who try to cover their antisemitism through the use of codes as "the East coast," leftist, "reputable antisemites" (Améry) are proud of their alleged anti-fascist engagement against Israel.

\section{New Antisemitism}

Especially since 9/11, a far-reaching ideological convergence of antisemitism has taken place across a range of ideologies and milieu that traditionally have precious little in common. At its heart lies a form of antisemitic anti-Zionism on which Islamists and many on the Far Right and the Left can agree. All of them see themselves and the world as the victims of some kind of Jewish-Zionist-capitalist conspiracy that is being played out in politics, the economy, and the media. ${ }^{25}$ This notion tends to merge closely with anti-Americanism, the critique of globalization, and anti-modernism.

In addition to Natan Sharansky's 3 Ds which help us pinpoint when the so called "Israel critique" is antisemitic-demonization, double standards, and delegitimization ${ }^{26}$-Monika Schwarz-Friesel and Jehuda Reinharz have introduced an overarching category: derealization. Derealizing linguistic utterances do not portray reality as it in fact is, but language is rather instrumentalized by the language-generators to verbalize aspects of the world as they view them. ${ }^{27}$ This leads to the derealization of current antisemitism, of the existing threats and attacks against Israel. This way "state terrorism" of the evil Goliath always appears disproportional.

24 Cf. S. Grigat, “Antisemitismus und Antizionismus in der Linken,” Hagalil.com, April 18, 2002, http://www.hagalil.com/antisemitismus/europa/linker-antisemitismus.htm.

25 Cf. O. Bartov, "Der alte und der neue Antisemitismus," in Neuer Antisemitismus? Eine globale Debatte, ed. D. Rabinovici et al. (Frankfurt am Main: Suhrkamp, 2004), 26-43.

26 Cf. N. Sharansky, "3D Test of Anti-Semitism: Demonization, Double Standards, Delegitimization,” Jewish Political Studies Review 16, no. 3-4 (2004), http://jcpa.org/article/3d-test-of-antisemitism-demonization-double-standards-delegitimization/.

27 Cf. M. Schwarz-Friesel and J. Reinharz, Inside the Antisemitic Mind: The Language of JewHatred in Contemporary Germany (Waltham: Brandeis University Press, 2017), 157. 
As the global anti-Zionist struggle that is being conducted on a daily basis by right-wing extremists, left-wing opponents of globalization, Arab fighters, and those motived by radical Islam unfolds, the book market is being flooded with publications whose authors tend to wear their hearts on their sleeves but also seek to distance themselves from the card-carrying antisemites. It is no longer a secret that left-wing anti-imperialism and the anti-globalization movement have a problem with antisemitism. On the one hand, there is the rampant anti-Zionism that turns various European and Social Justice forums into festivals of multi-cultural hatred against Israel. On the other hand, there is a form of critique of the global economic order, which has repeatedly been accused of arguing in a manner that is "structurally antisemitic." The ensuing controversy tends to hinge not on matters of substance but on the issue of correct terminology. Given that very few proponents of this agenda want to be classified as antisemites, the more sophisticated among them appropriate theories of antisemitism in order to develop modes of expression that have not been delegitimized by Adorno's critique. Some of them have understood that it is not opportune to display images that show the world in the arms of a repulsive octopus (though this imagery remains exceptionally popular among anti-globalization activists). Yet their underlying assumptions about the state and the economy remain the same, and they fail to critique the social phenomena which crystallize into antisemitism.

Even worse are the debates regarding Arab/Muslim antisemitism which, for the most part, simply fail to address the issue and principally focus on questions of terminology. Usually the first question raised is that of whether an antisemitic tradition existed in the Arab world or antisemitism was in fact imported from the West. The disparagement and contempt that the Islamic tradition displayed toward Jews doubtless influenced the ideologue of the Egyptian Muslim Brotherhood, Sayyid Qutb. ${ }^{28}$ Horkheimer, Adorno, and their colleagues insisted that modern antisemitism, while not divorced from its religiously motivated precursors, was nevertheless distinct from them due to the emergence of abstract forms of domination as capitalism transformed the world in its image. This same process has also taken place in the Arab world, though with a certain delay and under economically and politically less advanced circumstances. Traditional Catholic anti-Judaism may have influenced Hitler, but it is not central to an understanding of his antisemitism.

28 Cf. M. Küntzel, "National Socialism and Anti-Semitism in the Arab World," Jewish Political Studies Review 17, no. 1-2 (2005): 99-118. 
In this process anti-Jewish hatred there has been transformed into murderous modern antisemitism as well. Whether, in the past, Jews were persecuted in the same way in the Arab realm as they were in Europe is therefore not all too important. More important are the ideological processes that accompanied the capitalist transformation, and it is clear that in this context modern antisemitism has proven to be as successful in the Middle East as it was in Central and Eastern Europe.

The focus on pre-modern traditions thus signifies a fundamental lack of interest in the phenomenon of modern antisemitism from the outset and prevents a critique of the social conditions that allow antisemitism to enthuse the masses in Cairo as much as it inspires the Iranian regime. Even people who know about secondary antisemitism and may well have heard of "antisemitism without Jews" can suddenly account for antisemitism in the Middle East in no other way than by blaming the Jews. ${ }^{29}$

Insofar as social causes come into play at all, they are conceptualized as the ostensible consequences of European colonialism, once again turning the problem into one ultimately created by Europe. Those unwilling to tackle rigid sexual morals, genital mutilation, and the aggressively repressed homoeroticism of the Muslim ummah can obviously muster little more than a shrug of the shoulders when confronted with the suggestions that antisemitism has something to do with the repression of wishes and desires in an oppressive society.

As Omer Bartov has shown, a central element of "new antisemitism" is the belittlement of Islamist antisemitism in the western Left. The example he discusses is the speech of the Malaysian Prime Minister Mohamad Mahathir in 2003 at the Islamic Conference-in front of fifty-seven heads of states and two thousand journalists:

Today the Jews rule this world by proxy. They get others to fight and die for them. They, this tiny community, have become a world power. ... We cannot fight them through brawn alone. We must use our brains also. ... 1.3 billion Muslims cannot be defeated by a few million Jews. There must be a way. And we can only find a way if we stop to think, to assess our weaknesses and our strength, to plan, to strategise and then to counter attack. As Muslims we must seek guidance from the Al-Quran and the Sunnah of the Prophet. ${ }^{30}$

29 Cf. F. Markl, "Beschädigtes Leben und Judenhaß: Kritik des Antisemitismus als Gesellschaftskritik," in Feindaufklärung und Reeducation: Kritische Theorie gegen Postnazismus und Islamismus, ed. S. Grigat (Freiburg: Ça ira, 2006), 147.

30 "Dr Mahathir bin Mohamad at the opening of the tenth session of the Islamic Summit conference at Putrajaya Convention Centre,” issued October 16, 2003, accessed April 27, 2020, https://www.smh.com.au/world/mahathirs-full-speech-20031022-gdhmg3.html. 
In reaction to that, Paul Krugman wrote in the New York Times that the

remarks were inexcusable. But they were also calculated - for Mr. Mahathir is a cagey politician, who is neither ignorant nor foolish. ... Mahathir is ... about as forward-looking a Muslim leader as we're likely to find. ... So what's with the anti-Semitism? Almost surely it's part of Mr. Mahathir's domestic balancing act ... Now Mr. Mahathir thinks that to cover his domestic flank, he must insert hateful words into a speech mainly about Muslim reform. ${ }^{31}$

Krugman belittles Mahatir's antisemitism as a domestic strategy of a forwardlooking statesman and blames the US for antisemitism in the Muslim world. This derealization of Islamist antisemitism and anti-Zionism in the western Left has become a dominant part of a new, global antisemitism.

\section{New Antisemitism and New Media}

Against this theoretical background I argue that there is one significant distinction between the function of the new media for right-wing as opposed to leftwing users: the frequently discussed anonymity of the internet allows rightwing users to express antisemitic opinions more openly than they otherwise might. ${ }^{32}$ Left-wing users, by contrast, feel no urge to hide behind pseudonyms in the first place, since they are, after all, "virtuous antisemites." Many of them see themselves as antifascist activists, so why the need for anonymity? In this case, the problem lies elsewhere: left-wing and center-left new media platforms and forums claim that they ban not only racist and sexist but antisemitic content too. Yet anti-Zionism and the derealization of Islamist antisemitism turn out to be a blind spot-and thus the codes of conduct turn out to be a toothless tiger when it comes to leftist antisemitism.

In the following, I will analyze reactions to Hamas's new policy paper from May 2017 on leftist internet platforms and in the forum of the Austrian daily Der Standard. In scholarly literature that does not turn a blind eye toward Islamist

31 D. J. Goldhagen, “The Globalization of Antisemitism," Forward, May 2, 2003, https://forward. com/opinion/8736/the-globalization-of-antisemitism/.

32 Cf. R. Cohen-Almagor, "Countering Hate on the Internet," Annual Review of Law and Ethics 22 (2014): 431-43; S. Rohlfing, "Hate on the Internet," in The Routledge International Handbook on Hate Crime, ed. N. Hall et al. (London: Routledge, 2015), 296; for anonymity as a "new and effective" opportunity for relativising the Holocaust, see W. Benz, "Holocaust Denial: Anti-Semitism as a Refusal to Accept Reality,” Historein 11 (2011): 78. 
antisemitism, the Hamas Charter of 1988 is often presented as an example of blatant antisemitism. ${ }^{33}$ It claims:

Our struggle against the Jews is very great and very serious. ... The Movement is but one squadron that should be supported by more and more squadrons from this vast Arab and Islamic world, until the enemy is vanquished and Allah's victory is realised. ... The Zionist Nazi activities against our people will not last for long. ... The Prophet, Allah bless him and grant him salvation, has said: "The Day of Judgement will not come about until Moslems kill the Jews, when the Jew will hide behind stones and trees. The stones and trees will say O Moslems, O Abdulla, there is a Jew behind me, come and kill him." ${ }^{34}$

In 2017 Hamas sought to widen its international appeal at a time when the group faced "multiple challenges, including a dismal economic situation in Gazamost recently underscored by the energy crisis in Gaza-and strained relations with Egypt, which is at war with Hamas's parent organization, the Muslim Brotherhood." ${ }^{35}$ The relationship with the Iranian regime too had become tenuous. ${ }^{36}$ Its new policy paper of May 1, 2017, demonstrated the group's desire to appear more moderate and gain broader support: Hamas's

goal is to liberate Palestine and confront the Zionist project. ... Palestine, which extends from the River Jordan in the east to the Mediterranean in the west and from Ras Al-Naqurah in the north to Umm Al-Rashrash in the south, is an integral territorial unit. ... Hamas affirms that its conflict is with the Zionist project not with the Jews because of their religion. Yet, it is the Zionists who constantly identify Judaism and the Jews with their own colonial project and illegal entity. ... The Zionist movement, which was able with the help of Western powers to occupy Palestine, is the most dangerous form of settlement occupation which

33 Cf. B. Tibi, "From Sayyid Qutb to Hamas: The Middle East Conflict and the Islamization of Antisemitism," in The Yale Papers: Antisemitism in Comparative Perspective, ed. C. A. Small (New York: Institute for the Study of Global Antisemitism and Policy, 2015), 457-83; M. Litvak, "The Anti-Semitism of Hamas," Palestine-Israel Journal of Politics, Economics, and Culture 12, no. 2-3 (2005): 41-46; A. Pfahl-Traughber, "Antisemitismus und Antizionismus in der Charta der Hamas: Eine Fallstudie zur Judenfeindschaft im islamistischen Diskurs," in Dossier: Antisemitismus, ed. Bundeszentrale für politische Bildung (Bonn: bpb, 2011), 113-16.

34 Translation from http://avalon.law.yale.edu/20th_century/hamas.asp, accessed April 27, 2020.

35 M. Levitt and M. Rich, "Hamas's Moderate Rhetoric Belies Militant Activities," The Washington Institute for Near East Policy, issued May 1, 2017, accessed April 27, 2020, https://www. washingtoninstitute.org/policy-analysis/view/hamass-moderate-rhetoric-belies-militant-activ ities.

36 Cf. F. Markl, "Hamas-Angebot: Ergebnis der internationalen Isolation,” Mena-watch, September 18, 2017, https://www.mena-watch.com/mena-analysen-beitraege/hamas-angebot-ergebnisder-internationalen-isolierung/. 
has already disappeared from much of the world and must disappear from Palestine. ... Hamas rejects any alternative to the full and complete liberation of Palestine, from the river to the sea. However, without compromising its rejection of the Zionist entity and without relinquishing any Palestinian rights, Hamas considers the establishment of a fully sovereign and independent Palestinian state, with Jerusalem as its capital along the lines of the 4th of June 1967, with the return of the refugees and the displaced to their homes from which they were expelled, to be a formula of national consensus. ... There is no alternative to a fully sovereign Palestinian State on the entire national Palestinian soil, with Jerusalem as its capital. ${ }^{37}$

Hamas claims, then, that its conflict is with the Zionist project and "not with the Jews," yet it still demands that the Zionist project should "disappear from Palestine," which should be liberated "from the river to the sea." It refers to a "national consensus" calling for a return to the status quo ante, that is, the status prior to the Six-Day War of 1967, yet at the same time demands a Palestinian state "on the entire Palestinian soil."

Rather than discuss Hamas's claim that its conflict is not with the Jews but only with Zionism, I want to analyze reactions to the policy paper on the German-speaking Left. Needless to say, "the Left" in the post-Nazi German and Austrian context encompasses a broad range of positions.

Representative for the lunatic fringe of the discourse on Hamas, Israel, and the Middle East is "The Palestine Portal. Never again-No one-Nowhere." Its section on antisemitism bears the heading "No to antisemitism - no to its instrumentalization," which already indicates that the portal focuses on the denunciation of the critique of anti-Zionism. Before Hamas published its policy paper in 2017, the portal provided a link to a site, which presented Hamas as "not radical in its entirety" and "not the Taliban." Hamas was a group comparable to the PLO in the 1980s with which the Israelis and the US should negotiate. To exclude it from talks just because "the military arm of Hamas has carried out assassinations" would be "unfair." 38 In 2009, the portal claimed that continued reference to the 1988 Charter “completely ignores Hamas' development in the last ten years" ${ }^{39}$ from a resistance and activist group to a political party that relies on democratic means:

37 The Islamic Resistance Movement "Hamas," "A Document of General Principles and Policies,” issued May 1 2017, accessed April 27, 2020, http://hamas.ps/en/post/678/a-document-ofgeneral-principles-and-policies.

38 “Allgemein zum Sieg der Hamas," Frieden für Palästina 2006, issued 2006, accessed April 27, 2020, http://members.aon.at/friedenfuerpalaestina/aktuell/wahlen2006.htm.

39 “Hamas," Das Palästina Portal, issued January 26, 2009, accessed April 27, 2020, http://www. palaestina-portal.eu/Stimmen_deutsch/palaestina_heute_hamas.htm. 
The use of excerpts from the Charter as proof of Hamas's anti-Zionist militancy turns out to be rather embarrassing for those who quote them as soon as one makes the effort of putting those quotations back into the context from which they were torn. ${ }^{40}$

So even before the policy paper was published in 2017, the Palestine portal denied Hamas's antisemitism-only to clarify after its publication that while the Charter may have been radical,

the new [Hamas] document merely lends expression to forms of politics that have been undergoing a process of "moderation" for the past decade anyway. But because Hamas does now agree to a Palestinian state within the borders of 1967 (the two-state solution), Netanyahu needed to denounce Hamas as "rejectionist" on the grounds that it does not recognize Israel. ${ }^{41}$

No mention was made of the continued call to wipe Israel off the map. The Israeli reaction was immediately identified as the real problem: Netanyahu had argued that Hamas "brainwashes kids inside suicide camps," hence, the text's author suggested, "it would be interesting to look at some examples of the violent brainwashing of children by Israel" instead. It is worth mentioning that the equation of Israeli policies with those of the Nazis is standard fare for the portal's founder Erhard Arendt: "It was shocking for me to realize that those who used to be the victims have now become the perpetrators," he wrote on one occasion. ${ }^{42}$

More mainstream center-left media do not imply that the Israelis are the new Nazis, but they too pursue a similar derealization strategy, readily misinterpreting the Hamas Charter of 2017. In the German taz, Susanne Knaul claimed that

for the first time in its history Hamas has officially accepted the foundation of a Palestinian state only in the territories occupied by Israel. This paper no longer includes the explicit demand for the annihilation of Israel found in the Hamas Charter of 1988. The military wing has had to agree to turn its back on its founding fathers. ${ }^{43}$

40 Ibid.

41 J. Ofir, "Warum werden israelische Kinder einer Gehirnwäsche unterzogen, damit sie hassen?,” Das Palästina Portal, issued May 10, 2017, accessed April 27, 2020, http://palaestina-por tal.eu/texte/texte-7.htm.

42 “ProMosaik e.V. interviewt Herrn Erhard Arendt vom Palästinaportal," ProMosaik e.V., issued March 16, 2015, accessed October 1, 2018, https://promosaik.blogspot.com/2015/03/promosaikev-interviewt-herrn-erhard.html.

43 S. Knaul, “Die Hamas gibt sich versöhnlicher,” taz, May 2, 2017, https://www.taz.de/ArchivSuche/!5405601\&s=hamas/. 
Leaving to one side that the areas still under Israeli occupation would make for a rather limited Palestinian state, as we saw, Hamas's continued demand for the liberation of Palestine from the river to the sea explicitly calls for Israel's annihilation. Moreover, Hamas officials have made very clear that the paper does not in fact replace the Charter. ${ }^{44}$ In contrast to Leftist newspapers, the liberal German newspapers Die Zeit and Süddeutsche Zeitung do mention both of these points. ${ }^{45}$ In the liberal-conservative monthly Cicero, Michael Wolffsohn explicitly called the Hamas paper a new façade for an old building designed to hide Hamas' antisemitism. All too many, he lamented, were falling for this ruse. ${ }^{46}$

The Austrian center-left quality newspaper Der Standard reported on the Hamas policy paper on May 1, 2017, and on Netanyahu's response the following day. I will briefly mention the points raised in these two reports and then analyze the reactions to them in the Standard Online forum. Typical of center-left media, Standard Online wrongly referred to the Hamas paper as "a document in which Hamas accepts the establishment of a Palestinian state in the borders of 1967."47 A small minority of those posting responses to this article (four out of fifty-six) resorted to derealizing arguments. "Maynard52," for example, claimed that "Hamas never wanted to kill Jews because they are Jews, but to resist the Zionist occupiers. Have you actually realized that there is a brutal occupation regime in place?” Here, Hamas's crude antisemitism was simply denied altogether.

Another user posted under the name "Shitty little country," thus alluding to the infamous utterance of the then French ambassador in London, Daniel Bernard, three months after the attacks on 9/11. At a dinner party at the house of the then proprietor of The Telegraph, Conrad Black, and his wife, Barbara Amiel, Bernard had referred to Israel as a "shitty little country." On Amiel's account he had gone on to ask why the world should be "in danger of World War Three because of those people?"48 "I am only allowed to criticize Israel if the sit-

44 Cf. "New Hamas Policy Document 'Aims to Soften Image', BBC News, May 1, 2017, https:// www.bbc.com/news/world-middle-east-39744551.

45 Cf. "Hamas ändert ihre politischen Positionen,” Zeit online, May 1, 2017, https://www.zeit.de/ politik/ausland/2017-05/nahostkonflikt-hamas-aenderung-politisches-programm-israel; "Hamas ändert erstmals seit Gründung vor 30 Jahren ihr politisches Programm," Süddeutsche Zeitung, May 2, 2017, https://www.sueddeutsche.de/politik/palaestinenserorganisation-hamas-aenderterstmals-seit-gruendung-ihr-politisches-programm-1.3486326.

46 Cf. M. Wolffsohn, "Neue Fassade, altes Haus,” Cicero. Magazin für politische Kultur, May 8, 2017, https://www.cicero.de/aussenpolitik/hamas-paper-neue-fassade-altes-haus.

47 "Hamas will womöglich Grenzen von 1967 akzeptieren," Standard Online, May 1, 2017, https://derstandard.at/2000056825376/Hamas-will-womoeglich-Grenzen-von-1967-akzeptieren.

48 “Daniel Bernard (obituary)," The Telegraph, May 3, 2004, https://www.telegraph.co.uk/ news/obituaries/1460855/Daniel-Bernard.html. 
uation has changed???” the user who had chosen to post under this name asked indignantly and went on: "But the current system in which everyone who criticizes Israel is an antisemite actually works quite well.” The claim that one is not allowed to criticize Israel and that any and every critique of Israel is automatically considered antisemitic is, of course, a central plank of the anti-Zionist "critique of Israel," even though there is a clear and obvious distinction between criticisms of specific policies or actions of the Israeli government or military and the comprehensive delegitimization of Israel. ${ }^{49}$ Another user, "Jtiberius," wrote: "Don't worry, Israel will continue to receive more money for its illegal policy than Hamas." "Which one?”, another user asked. “The illegal settlement policy. The illegal policy of defense. The illegal human rights policy," "Jtiberius" responded. In the world of conspiracy theories, it seems self-evident that Israel is receiving money from non-specified outside forces. The policy of defense is tied together with the debatable settlement policy so that both can be portrayed as illegal in the same way.

A second report published by the Standard Online dealt with the reaction of the Israeli government to the Hamas paper and wrongly claimed, yet again, that "Hamas has dropped the call for the destruction of Israel."50 Since the main topic of this second article was Israel, the tone of the responses became much harsher. "Hellene Kurz" resorted to one of the most common demonization strategies when she asked: "what do you expect from the war mongers netanjahu \& co." "Der_wiedergänger" meanwhile was sure that "the Palestinians can try whatever they want - it will never be enough for Israel. Q.E.D.-it becomes clear once again who is standing in the way of peace." "Callimachus," who regularly takes issue with this narrative in the Standard forum, summed up the antiZionist derealization in the following way: "Self defense is war. Terror is resistance. Peace is the destruction of Israel." Taken out of context, his remark might even be mistaken for a particularly drastic antisemitic comment.

Alongside the identification of Israeli war-mongering as the sole source of conflict, equating Israel with Apartheid South Africa is another popular delegitimization strategy. The user "Minced Meat” wrote: "I call Israel's policy Apartheid, and I am absolutely right." Note the absence of an actual argument and the self-assuredness. That a coalition of four Arab-dominated parties, the "Joint list,"

49 Cf. for examples of obviously not antisemitic criticism of Israeli policies, see M. SchwarzFriesel and J. Reinharz, Die Sprache der Judenfeindschaft im 21. Jahrhundert (Berlin: De Gruyter, 2013), $200-202$.

50 “Israel nennt neue Hamas-Richtlinien 'Täuschungsmanöver'," Standard online, May 2, 2017, https://derstandard.at/2000056844305/Israel-nennt-neue-Hamas-Richtlinien-Taeuschungsmano ever. 
is currently the third largest party in the Israeli parliament or that Salim Joubran served as the country's first Arab Supreme Court justice from 2003 to 2017, facts like these are simply ignored. ${ }^{51}$ "My soul slides away" was sure that "over $95 \%$ of schools are segregated. In my eyes this is racial segregation!” On similar grounds

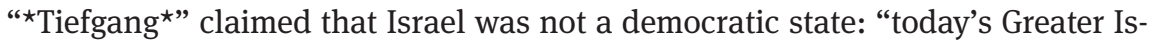
rael is a product of robbery and will never be accepted in this form. But Israel does not care about this either. Israel prefers to stay an exclusively Jewish state, a theocracy, instead of constituting itself as a democratic state."

A user calling himself "Staatsvertrag," finally, implied that Israel was doing to the Palestinians what the Nazis had done to the Jews. Responding to a user who had pointed out that Israel had withdrawn from the Gaza Strip in order to obtain peace for land and that Hamas was entirely to blame for the comprehensive Egyptian and partial Israeli blockades, "Staatsvertrag" asked: "Which 'land' was given [back]? Definitely not Gaza: Gaza is still under siege and an open-air prison. A ghetto." The depiction of the Israelis as the new Nazis who keep the Palestinians in a ghetto is a well-established trope in "antifascist antisemitism."

It is important to note that Standard Online is the moderated forum of arguably the most respectable quality newspaper in Austria. According to its code of conduct, "no racist, sexist, misogynic, homophobic, antisemitic or other misanthropic posts" 53 are allowed. Yet anti-Zionism and denial of Israel's right to exist are evidently not considered problematic. Not even the equation implied by referring to Gaza as a ghetto is identified and censored as antisemitic.

As opposed to right-wing antisemitism, left-wing antisemitism does not blossom under the protection of anonymity. It is self-assured and forthright. It is high time that new media platforms and forums firmly incorporate anti-Zionism into their definitions of antisemitism. They need to ban postings, which claim that Israel is an Apartheid state, imply or openly demand that it must be destroyed or dismantled, or suggest that Gaza is a ghetto and thus imply that the Israelis are the new Nazis. None of this has anything to do with censoring criticism of Israeli

51 Cf. Y. J. Bob, “The Legacy of Israel's First Arab Supreme Court Judge,” The Jerusalem Post, August 4, 2017, https://www.jpost.com/International/The-legacy-of-Israels-first-Arab-SupremeCourt-judge-501567.

52 In the Austrian context, the name "Staatsvertrag" alludes to the Treaty for the Re-Establishment of an Independent and Democratic Austria. Signed by the Allied occupying powers and the Austrian government in Vienna in 1955, it re-established Austria as a sovereign state in 1955, ending ten years of Allied occupation.

53 "Community-Richtlinien," Standard Online, https://derstandard.at/2934632/ForenregelnCommunity-Richtlinien. 
policies or actions. Nor does the critique of leftist anti-Zionism and the leftist tendency to whitewash Islamist antisemitism amount to the claim that "the Left" is antisemitic. Yet neither, given its prevalence in centrist and center-left media, can one dismiss the problem of secondary, post-Holocaust antisemitism simply as a problem of the extreme right and a few activists on the loony left.

Ljiljana Radonić heads a project on "Globalized Memorial Museums. Exhibiting Atrocities in the Era of Claims for Moral Universals" at the Institute of Culture Studies and Theatre History of the Austrian Academy of Sciences, funded by the European Research Council. Her habilitation project on "World War II in Post-Socialistic Memorial Museums" was funded by the APART post-doc fellowship at the Austrian Academy and the Elise-Richter-Program of the Austrian Science Fund - FWF. Radonic has been teaching at the Department of Political Science at the University of Vienna since 2004.

\section{References}

Adorno, Theodor W. "Was bedeutet: Aufarbeitung der Vergangenheit." In Gesammelte Schriften 10.2. Kulturkritik und Gesellschaft II: Eingriffe. Stichworte, 555-72. Suhrkamp: Frankfurt am Main, 1977.

Adorno, Theodor W. "Zum Verhältnis von Soziologie und Psychologie." [1955] In Soziologische Schriften 1, 42-85. Frankfurt am Main: Suhrkamp, 1999.

Adorno, Theodor W., Else Frenkel-Brunswik, Daniel Levinson, and Nevitt Sanford. The Authoritarian Personality. New York: Harper \& Row, 1950.

Améry, Jean. "Der ehrbare Antisemitismus. Rede zur Woche der Brüderlichkeit." In Weiterleben-aber wie? Essays 1968-1978, 151-75. Stuttgart: Klett-Cotta, 1982.

Bartov, Omer. "Der alte und der neue Antisemitismus." In Neuer Antisemitismus? Eine globale Debatte, edited by Doron Rabinovici, Ulrich Speck, and Natan Sznaider, 26-43. Frankfurt am Main: Suhrkamp, 2004.

Benz, Wolfgang. "Holocaust Denial: Anti-Semitism as a Refusal to Accept Reality." Historein 11 (2011): 69-79.

Bob, Yonah Jeremy. “The legacy of Israel's first Arab Supreme Court judge." The Jerusalem Post, August 4, 2017. https://www.jpost.com/International/The-legacy-of-Israels-firstArab-Supreme-Court-judge-501567.

Bohleber, Werner and John S. Kafka, eds. Antisemitismus. Bielefeld: Aisthesis, 1992.

Cohen-Almagor, Raphael. "Countering Hate on the Internet." Annual Review of Law and Ethics 22 (2014): 431- 43.

Freud, Sigmund. "Mann Moses und die monotheistische Religion.” [1939] In Studienausgabe IX: Fragen der Gesellschaft. Ursprünge der Religion. Frankfurt am Main: Fischer, 2000.

Goldhagen, Daniel Jonah. "The Globalization of Antisemitism.” Forward, May 2, 2003. https:// forward.com/opinion/8736/the-globalization-of-antisemitism/. 
Grigat, Stephan. "Antisemitismus und Antizionismus in der Linken.” Hagalil.com, April 18, 2002. http://www.hagalil.com/antisemitismus/europa/linker-antisemitismus.htm.

Haury, Thomas. Antisemitismus von links: Kommunistische Ideologie, Nationalismus und Antizionismus in der frühen DDR. Hamburg: Hamburger Edition, 2002.

Haury, Thomas. "Die Ideologie, die nicht vergehen will. 35 Jahre antisemitischer Antizionismus in der Neuen deutschen Linken." In Trotz und wegen Auschwitz: Antisemitismus und nationale Identität nach 1945, edited by AG Antifa/Antira im StuRa der Uni Halle, 92-114. Münster: Unrast, 2004.

Hirsh, David. Contemporary Left Antisemitism. London: Routledge, 2018.

Horkheimer, Max. "Die Juden und Europa." In Wirtschaft, Recht und Staat im Nationalsozialismus. Analysen des Instituts für Sozialforschung 1939-1942 von Max Horkheimer, edited by Helmut Dubiel and Alfons Söllner. Frankfurt am Main: Suhrkamp, 1984.

Horkheimer, Max and Theodor W. Adorno. Dialektik der Aufklärung. Philosophische Fragmente. Frankfurt am Main: Suhrkamp, 1997.

Knaul, Susanne. “Die Hamas gibt sich versöhnlicher.” taz, May 2, 2017. https://www.taz.de/ Archiv-Suche/!5405601\&s=hamas/.

Kohn-Ley, Charlotte. “Antisemitische Mütter-antizionistische Töchter?” In Der feministische "Sündenfall"? Antisemitische Vorurteile in der Frauenbewegung, edited by Charlotte Kohn-Ley and Ilse Korotin, 209-30. Wien: Picus, 1994.

Küntzel, Matthias. "National Socialism and Anti-semitism in the Arab World." Jewish Political Studies Review 17, no. 1-2 (2005): 99-118.

Levitt, Matthew and Maxine Rich. "Hamas's Moderate Rhetoric Belies Militant Activities." The Washington Institute for Near East Policy, May 1, 2017. https://www.washingtoninstitute. org/policy-analysis/view/hamass-moderate-rhetoric-belies-militant-activities.

Litvak, Meir. "The Anti-Semitism of Hamas." Palestine-Israel Journal of Politics, Economics, and Culture 12, no. 2-3 (2005): 41-46.

Markl, Florian. "Beschädigtes Leben und Judenhaß. Kritik des Antisemitismus als Gesellschaftskritik." In Feindaufklärung und Reeducation. Kritische Theorie gegen Postnazismus und Islamismus, edited by Stephan Grigat, 131-53. Freiburg: Ça ira, 2006.

Markl, Florian. "Hamas-Angebot: Ergebnis der internationalen Isolation." Mena-watch, September 18, 2017. https://www.mena-watch.com/mena-analysen-beitraege/hamas-an gebot-ergebnis-der-internationalen-isolierung/.

Marx, Karl. Das Kapital. Kritik der politischen Ökonomie. Berlin: Dietz, 1993.

Ofir, Jonathan. "Warum werden israelische Kinder einer Gehirnwäsche unterzogen, damit sie hassen?” Das Palästina Portal, May 10, 2017. http://palaestina-portal.eu/texte/texte-7. htm.

Pfahl-Traughber, Armin. "Antisemitismus und Antizionismus in der Charta der Hamas. Eine Fallstudie zur Judenfeindschaft im islamistischen Diskurs." In Dossier: Antisemitismus, edited by Bundeszentrale für politische Bildung, 113-16. Bonn: bpb, 2011.

Rabinovici, Doron, Ulrich Speck, and Natan Sznaider, eds. Neuer Antisemitismus? Eine globale Debatte. Frankfurt am Main: Suhrkamp, 2004.

Rensmann, Lars. "Guilt, Resentment, and Post-Holocaust Democracy: The Frankfurt School's Analysis of 'Secondary Antisemitism' in the Group Experiment and Beyond." Antisemitism Studies 1, no. 1 (2017): 4-37. 
Rensmann, Lars. Kritische Theorie über den Antisemitismus: Studien zu Struktur, Erklärungspotential und Aktualität. Berlin/Hamburg: Argument, 1998.

Rohlfing, Sarah. "Hate on the Internet." In The Routledge International Handbook on Hate Crime, edited by Nathan Hall, Abbee Corb, Paul Giannasi, and John G. D. Grieve, 293-304. London: Routledge, 2015.

Schwarz-Friesel, Monika. Antisemitism 2.0 and the Cyberculture of Hate. Hostility towards Jews as a cultural constant and collective emotional value in the digital age (short version). Berlin: Technische Universität Berlin, 2018. https://www.linguistik.tu-berlin.de/ fileadmin/fg72/Antisemitism_2.0_short_version_final2.pdf.

Schwarz-Friesel, Monika and Evyatar Friesel. “'Gestern die Juden, heute die Muslime...'? Von den Gefahren falscher Analogien." In Islamophobie und Antisemitismus - ein umstrittener Vergleich, edited by Gideon Botsch, Olaf Glöckner, Christoph Kopke, and Michael Spieker, 29-50. Berlin: de Gruyter, 2012.

Schwarz-Friesel, Monika and Jehuda Reinharz. Die Sprache der Judenfeindschaft im 21. Jahrhundert. Berlin: De Gruyter, 2013.

Schwarz-Friesel, Monika and Jehuda Reinharz. Inside the Antisemitic Mind: The Language of Jew-Hatred in Contemporary Germany. Waltham: Brandeis University Press, 2017.

Sharansky, Natan. "3D Test of Anti-Semitism: Demonization, Double Standards, Delegitimization." Jewish Political Studies Review 16, no. 3-4 (2004). http://jcpa.org/ar ticle/3d-test-of-anti-semitism-demonization-double-standards-delegitimization/.

Silbermann, Alphons. Der ungeliebte Jude. Zur Soziologie des Antisemitismus. Zürich: Interfrom, 1981.

The Islamic Resistance Movement "Hamas." "A Document of General Principles and Policies." Issued May 1, 2017. Accessed April 27, 2020. http://hamas.ps/en/post/678/a-documentof-general-principles-and-policies.

Tibi, Bassam. "From Sayyid Qutb to Hamas: The Middle East Conflict and the Islamization of Antisemitism." In The Yale Papers: Antisemitism in Comparative Perspective, edited by Charles Asher Small, 457-83. New York: Institute for the Study of Global Antisemitism and Policy, 2015.

Wolffsohn, Michael. "Neue Fassade, altes Haus." Cicero. Magazin für politische Kultur, May 8, 2017. https://www.cicero.de/aussenpolitik/hamas-paper-neue-fassade-altes-haus.

World Jewish Congress and Vigo Social Intelligence. The Rise of Antisemitism on Social Media. Summary of 2016. New York: World Jewish Congress, 2016. 